\title{
Development Induced Displacement; A Review of Risks Faced by Communities in Developing Countries
}

\author{
Caroline Aboda ${ }^{1, *}$, Frank Mugagga ${ }^{2}$, Patrick Byakagaba ${ }^{2}$, Goretti Nabanoga ${ }^{3}$ \\ ${ }^{1}$ Department of Geography, Geo-informatics and Climatic Sciences, School of Forestry and Environmental Sciences, Makerere \\ University, Uganda \\ ${ }^{2}$ Department of Environmental Management, School of Forestry and Environmental Sciences, Makerere University, Uganda \\ ${ }^{3}$ Department of Extension and Innovation Studies, School of Agricultural production, Makerere University, Uganda
}

Copyright@2019 by authors, all rights reserved. Authors agree that this article remains permanently open access under the terms of the Creative Commons Attribution License 4.0 International License

\begin{abstract}
About 15 million people every year are forced to live their homes to give way for huge development projects such as dams, highways, and mining. In most developing countries, such projects have been noted to increase ecological and social vulnerability, thus leaving the affected people displaced, disempowered and destitute. The literature review paper focused on the different risks communities are exposed to due to development induced displacement and resettlement. The data presented is review of online peer-reviewed and grey literature between the years 1980 through 2018. The risks analyzed through the Impoverishment, Risk and Reconstruction (IRR) model acts as a guide in selecting and understanding the risks of development induced displacement and Resettlement (DIDR) during social vulnerability assessment. Often the question of social vulnerability has been largely ignored due to the difficulty in quantification. Risk analysis also provides ground to further investigate reasons for the occurrence and persistency of the risks, in developing countries such as India, Sudan and Kenya. The findings of the review through the IRR model indicated that displacement and resettlement exposes project affected people to some opportunities, but largely associated with more risks. Some of the reasons for the persistency of the risks included; compensation for lost properties and lack of experience and capacity to handle resettlement processes. Identifying reasons for the persistency of the already known risks, especially in developing countries builds on the previous work on DIDR risks by Micheal Cernea and other researchers.
\end{abstract}

Keywords Consequences, Communities, Development Induced Displacement, Risks, Developing Countries

\section{Introduction}

In most developing countries such as China, India,
Zambia, Ghana large scale development projects have rendered increasingly sizeable population homeless, landless, jobless and food insecure, considering that their socio-economic asset base is often destroyed (Oliver-Smith 2009; Bond and Kirsch 2015). Globally, it is estimated that in the current decade 2010-2019, approximately 15 million people are forced to leave their homes to give way for huge development projects every year (Terminiski 2015). The effects of such development projects; dams, transportation, water supply, and industrial construction has led to subjection of displaced population to being susceptible to environmental and socio-economic changes (Robinson 2003; Stanley 2004; Terminiki 2013). Such projects have been noted to increase ecological and social vulnerability of the affected people (Caspary 2007; Oliver-Smith 2009). Women, the elderly and children often experience the greatest impact due to their inherent social vulnerabilities (Stanley 2004; Mehta 2009; Terminiski 2011).

More development induced displacements can be seen in developing regions of Asia and Africa (Terminiski 2013). Some of the examples include; the construction of the Three Gorges Dam in China that displaced 1.13 million people for more than two decades (Wilmsen 2016). The development of the Marange Diamond fields in the Chiadzwa area in Zimbabwe that led to resettlement of 4,700 Chiadzwa villagers. Kariba Dam construction in Zambia displaced approximately 57,000 people (Stanley 2004). In Uganda, the proposed construction of the oil refinery at Kabaale parish in Hoima District led to displacement of 1221 households affecting over 7000 people (Ministry of Energy and Mineral Development 2012). In Ghana, (Boohene and Peprah 2011) found that most fishermen and fish mongers including their dependants were displaced in oil production areas. The consequences bring about changes in the way people live, play, work and relate to each other and cope as a community (Bozigar et al. 2015). Recent studies have shown that the inability to respond, cope and recover from 
the negative impacts makes some people especially those that are weak and poor more vulnerable (Prencel and Vancaly 2014).The people that face and suffer from such infrastructural development are often oppressed by the power and rules of nations (Terminiski 2011).

In his multiple studies, Cernea (1990; 2000; 2005; 2009) identified some risks associated to development induced displacements including; landlessness, homelessness, joblessness, food insecurity, loss of access to common property resources, increase in diseases, social disintegration. The model offers a valuable tool for the assessment of the many risks inherent in development induced displacement (Rajagopal 2000). The risks analyzed could be used as a mirror to select and understand the risks households are exposed to as a result of development induced displacement during social vulnerability assessment, hence offering grounds to investigate factors accounting for the continued occurrence and persistency of those risks.

Development induced displacement is a situation where people are forced to leave their homes due to development projects such as the construction of dams, industries, roads, and airports. Downing and Garcia-Downing (2009) observed that there was need to understand the connection between developments imposed shocks like those resulting from displacement and household vulnerability (Caspary 2007). Understanding social vulnerability could act as the first line action in minimizing vulnerability to the consequences of an event (Marshall et al. 2014) such as that of large scale development induced displacement and resettlement.

In this paper, we examine the different risks due to development induced displacement by dams, roads, highways and industrial construction in developing countries. The focus is characterizing risks that communities could be exposed to, as informed by the Impoverishment Risks and Reconstruction (IRR) model that was developed by Cernea (1990).

\section{Method and Conceptual Framework}

According to Korichera and Gurevitch (2013) meta-analysis employed in literature review for this study has been described as one of the commonly used tool in the social science and environmental change studies. Meta-analysis is based on general principles through the systematic assessment of carefully selected literature. This study involved an extensive search and review of both peer reviewed and grey literature published from 1980 through 2018 describing the risks due to displacement and resettlement in the context of development projects. Internet searches were performed on online databases such as Google Scholar, Wiley online library and Google (www.google.com). Grey literatures were gathered from various relevant institutional websites. The keywords used as search filters included; ["Development induced displacement"]. A total of 223 articles, reports and policy documents were collected based on tittle. From Google scholar, Google and Wiley online library, the first search results; 150,46 and 20 articles respectively were selected based on title. After reading through the abstracts of the collected articles, we selected 97 article focused on development induced displacement and resettlements. The articles included had specific focus on the consequences or outcomes, problems or challenges and risks of development induced displacement and resettlement. Thirty nine (39) articles were excluded because they were not relevant to this study. The 39 articles focused on resettlement due to climate change, international law and resettlement, poverty risks and environmentally induced migration. Others were; political responses, contested urban landscapes and articles focused on developed countries such as United States of America, Norway. Fourteen (14) articles duplicated in the online databases were also excluded; nine (9) articles were later added based on citations in the papers reviewed. Only full papers with the necessary content(s) and areas of interest obtained through survey, interviews, focus group discussions and literature review were read and retained. During literature search, some of the developing countries noted to have experienced displacement and resettlement risks included; China, India, Indonesia, Kenya, Bangladesh, Ethiopia, and Sudan

The paper employed the Impoverishment Risk and Reconstruction Model (IRR) as predictor of risks and challenges that communities could be exposed to due to displacements and resettlements by development projects such as dams, highways, industries and waste management plants.

\section{The Impoverishment, Risk and Reconstruction (IRR) Model}

The Impoverishment Risks and Reconstruction (IRR) Model for Resettling Displaced Populations was developed by Cernea in the late 1990s after Scudder and Colsons four stage model of voluntary resettlement (Stanley 2004). Cernea is credited for his work and coming up with the term "development-induced displacement and resettlement" (DIDR) (Vivoda et al. 2017). The IRR model is a conceptual and theoretical framework for identifying and analyzing the inherent risks associated to impoverishments that displaced and resettled people suffer (Cernea 2000). There are majorly two foundational models that help in explaining Development Induced Displacement and Resettlement in most literatures. The models were developed not only to explain the challenges involved in development induced displacement and resettlement processes but displacement and resettlement in general. Scudder and Colson developed the first model in 1982. In their work, displacement and resettlement was seen as a 
four stage process including; recruitment, transition, recovery, and handing over or incorporation. The four stages model was initially formulated to explain the stages of voluntary resettlement but was later applied to involuntary resettlement contexts (only in situations where all the four stages appeared successful) (Patridge 1989). By the late 1980s and 1990s, there was realization that involuntarily displaced people were not experiencing all the four stages. Instead of resettled people recovering, it was the opposite due to the impoverishment risks. There arose the need for a new model to help in identifying the risks and consequences that impoverishes displaced and resettled people. In response to this gap, Cernea's IRR model was then developed and formulated (Cernea 1990) The IRR model aims to identify the impoverishment risks that development projects pose on displaced persons and how the livelihoods of displaced persons could be rebuilt and restored in relocation areas (Cernea 2000).

The IRR model was developed through a series of empirical studies for over two decades of intensive resettlement research worldwide. Several studies (Mahapatra 1999; Muggah 2002; Vivoda \& Owen, 2017; Ambaye and Abeliene 2015) applied the IRR model to test its applicability in different resettlement contexts. Assessing the risks associated to development induced displacements and resettlements through the IRR model acts as an opening for researchers to investigate the reasons why such risks after being known for over two decades of research and other experiences, still persist in most developing countries which among include; China, India, Ghana, Nigeria and Uganda.

Guided by the Impoverishment Risk and Reconstruction Model, the literature was thematically synthesized in relation to the important risks related to development induced displacement including: landlessness, homelessness, joblessness, food insecurity, increased morbidity, social disarticulation, marginalization and loss of access to community resources as seen in figure 1 .

\section{A framework for analyzing the impoverishment risks of involuntary displacement}

and resettlement and consequences

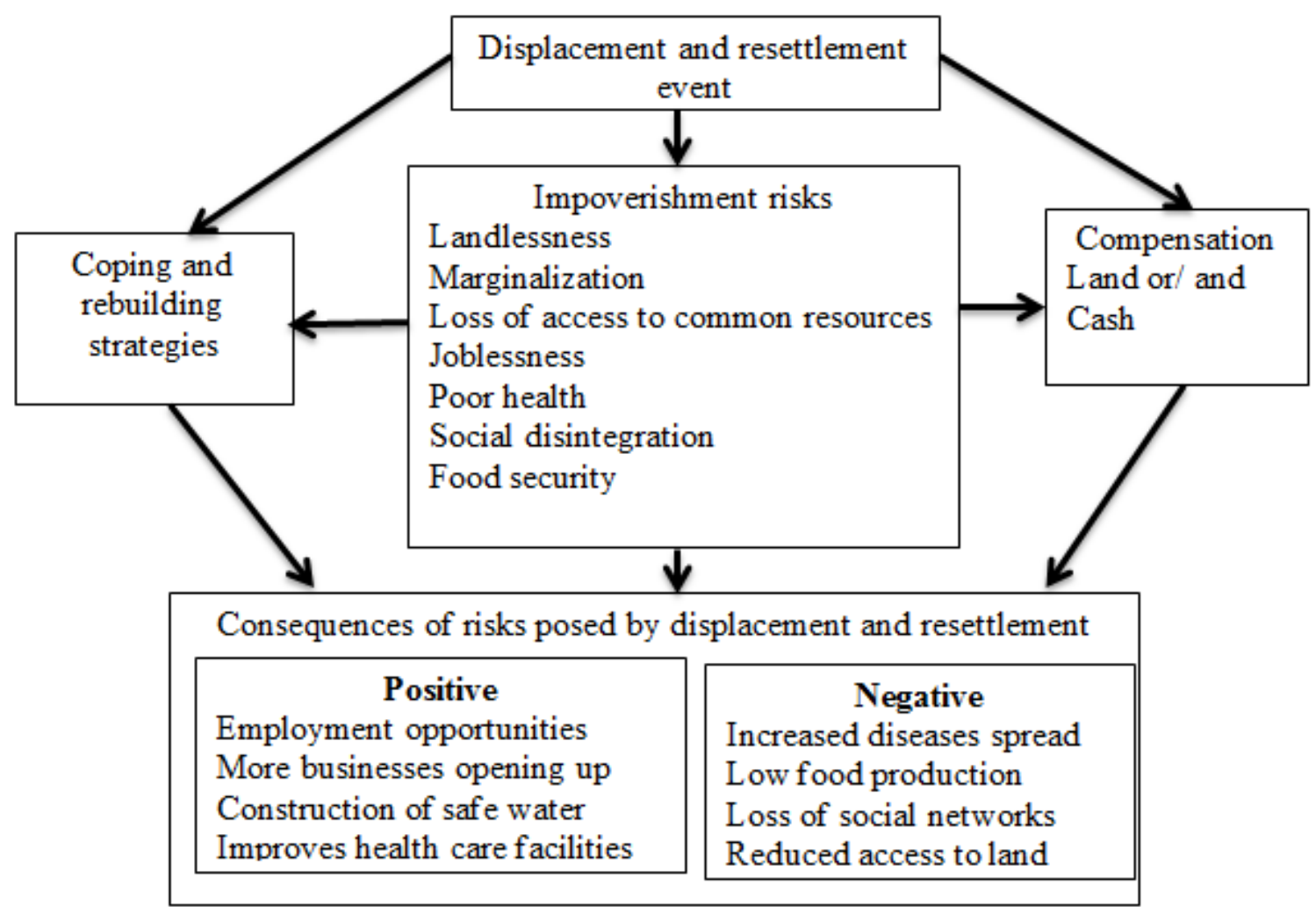

Figure 1. Adopted from Cernea's IRR model (1990) and modified by Author 
The IRR model adopted was modified to include the consequences of development induced displacement and resettlement risks and measures to cope with the risks and negative consequences. According to the IRR model, exposure to displacement and resettlement event impoverishment risks affects assets or resources owned by affected people either positively or negatively. Compensations in terms of either land or cash could help in coping and rebuilding livelihoods in relocation areas.

\section{Findings}

\subsection{Landlessness}

Land is a livelihood asset for the majority of the rural communities (Bessey and Tay 2015). It is central to economic development, acts as social security and a sense of belonging (African Progress Panel 2012). Development projects often lead to loss of land and worse impose restrictions on land use and access to forests, protected area and demarcated parks (Perera 2014). Africa Progress Panel (2012) observed that worldwide the acquisition of land for development related projects covered over 203 million hectares, Africa 134 million hectares- an area larger than UK, Germany and France. Loss of land hurts the affected people more (Rodhouse and Vanclay 2016). The Loss of land to development projects make communities who depend on land for hunting-gathering economy, with few employment options, more at risk of multi-generational economic marginalization (Somayaji and Talwar 2011). In addition, loss of land to development projects deprives the communities of their commercial activities, productive and livelihood assets, hence making the affected people impoverished (Vagholikar and Das 2010; Terminiski 2012). For instance, land acquisition for the purpose of building industries in Singur and Nandigram in West Bengal led to economic hardships for many of the rural people. In Singur, majority of the rural population were not offered adequate compensation, hence resulting in $40 \%$ lower income growth of owners and half that of tenants (Guha 2007). According to Mburugu (1993), Kiambere hydropower project in Kenya after displacement, farmers yield substantially decreased due to the size of land owned. Average land holdings dropped from thirteen to six hectares. The decrease in average land holdings also affected the number and type of livestock owned. In his studies in Bangladesh, Al Atahar (2010) found that land acquisition for the Jamuna Bridge project severely affected average people as more than 7,000 acres of land was taken, affecting 16,500 directly and indirectly in a population of 100,000 households. Several affected households were neither compensated nor rehabilitated yet they were already living under difficult conditions. In a similar study, Ambaye and Abeliene (2015) found that the size of land allocated to displaced households was smaller than the previous before displacement. The effects of development induced displacement and resettlement is devastating especially for the indigenous people who value land as a source of identity and way of life (Hoshour and Kalfut 2010). The loss of access to land including common property resources means immediate and serious outcome for food insecurity and increased poverty (Tsikata 2009; Adusah kari-kari 2015).

\subsection{Marginalization}

According to Cernea $(2000 ; 2009)$, marginalization is considered to be more of an individualized process and occurs when families or individuals experience a back slide and or lose economic power. When households are resettled, they have to adjust to the new situation in terms of environment, lifestyle, skills which may be outdated in the new settlement area. Ahsan (2016) in his study in East Malaysia, found that displacement due to a mega infrastructural project had made the displaced households particularly those with elderly people more marginalized. This is because the elderly people who were used to fishing, farming and socializing could not adjust or cope with modern technologies. In a similar study, Bharali (2007) found that people displaced by development projects were affected in terms of yield produced from their farming activities. Most of those farmers who owned bigger plots of land became medium; the medium farmers land became small. Famers that owned small and marginal plots of land, became landless, hence making such households to be more marginalized than before the displacement.

\subsection{Loss of Access to Common Property Resources}

Displacement due to development activities commonly result into loss of livelihood resources like acquisition of non-private resources including forest land (Kabra and Mahalwal 2014). Access to natural resources such as land and common property resources from which they previously derived their livelihood sources like food and income could be affected (Oruonye 2012). Therefore the loss of access to those livelihood resources often socially and economically puts such marginalized communities in worse situations (Chakravorty 2013). The loss of common property resources such as grazing lands, burial grounds, and forested lands often lead to loss of income and livelihood (Cernea 1997). The effects of losing common property resources affects both men and women but women feel the effects more due to the division of labour which makes them in charge of reproductive tasks for their households (Cernea 2006; Adusah Kari-Kari 2012). Difficulty in accessing common property resources such as lakes, rivers, forests limits women with their customary economic activities including collecting firewood and also partly providing food for the family as their roles. Men are more in charge of production and decision making when 
common property resources are lost while women tend to suffer in various ways during such situations (Fernandes 2008). When common property resources are lost, encroachment and pressure on reserved forests, rivers, and grasslands of the host area population increases by the displaced people, hence negatively affecting their ecological resilience (Terminiski 2012). In their visit to the IB Valley Coal field in the Indian State of Odisha in 2012, Sahoo and Mishra (2016) interacted with women who stated that much as life was difficult before displacement by the Coalfield mining operation. At least they had access to some common property resources such as water from the local river, fuel and fodder from the forests.

\subsection{Homelessness}

Inadequate compensation of the displaced leads to both landlessness and homelessness (Somayaji and Talwar 2011). Besides difficulty in meeting labor and financial costs in rebuilding a house in the shortest time possible, resettled people's financial capacity may worsen since they have to pay more money to rent a house (Ambaye and Abeliene 2015). Patel et al. (2015) in their studies found that more than 80 percent of the affected population lived in temporary, structurally unsafe shelters in the resettlement site. In the resettlement site displaced population were faced by inadequate water, sanitation and health services. Tadesse (2007) in his studies in Boreda, Ethiopia found that the shelters provided to the resettlers were poorly constructed. Homelessness also resulted into one of the major impoverishment risk for the former inhabitants at Teberebie in Ghana who were displaced by the American-Ghanaian gold mining company Teberebie Goldfields Ltd (Downing 2002). When people lose homes, several livelihood assets are lost too; a transportation cost for assets to the resettlement site becomes high; the cost of constructing houses on a new site also increases. Other effects include; increased deprivation of water, sanitation, education and health services; together with loss of cultural space and identity, leading to alienation, and impoverishment (Cernea 2000).

\subsection{Joblessness}

Although development projects offer employment opportunities, rarely are the local people employed in the unskilled, semi-skilled and skilled section (Vagholikar and Das 2010). Manjula et al. (2013) in their studies in Kerala, India on the consequences of Development Induced Displacement found that land acquisition resulted into displacement which had an effect on the employment rates of the affected population. "The Work Participation Rates before and after displacement among those displaced from the sample project sites in Kerala tremendously declined. Before displacement $47.62 \%$ of the total working age population used to be engaged in work and this percent declined to 35.41 after land acquisition. Kial, one of the cities in the study area in Kerala had the highest work participation rates 57.21 and 42.93 percent among the three project sites both before and after displacement, followed by Techno City and then by ICTT. In all three project sites, there was drastic reduction in the Work Participation Rates". A study by (Randell 2016) in the Brazilian Amazon found out that 34 percent of households interviewed reported that it was difficult getting another job after displacement. A farmer whose income declined after displacement stated, "There we had cacao and the land was good for raising chickens, and here it is neither good for chickens nor cacao...here is more difficult, because now we only have cattle". Pandey (1996) survey on the impacts of development induced displacement on people among tribal households in five villages at Talcher, Orissa in India, found that there was an increase in unemployment from $9 \%$ to $43.6 \%$, followed by a large shift from primary to tertiary occupations with reductions in levels of earnings between 50 and $80 \%$ tribes. Similar study by Patel et al. (2015) observed that " 14 percent of workers remained chronically unemployed at the time of their survey and 38 percent had lost income days, with an average loss of 28 days". When the affected population relocated to the resettlement site, 26 percent were unemployed and some of those who found employment had to walk an average of 3.74 kilometres to work. Therefore, in order to reduce vulnerability, jobs need to be available; otherwise, the resettled population could remain dependent on external resources, hence making reconstruction of livelihoods to remain incomplete (Oliver-Smith 2009).

\subsection{Social Disintegration}

Community networks positively affect resilience and help in creating a supportive environment (Cooke 2015). Individuals and communities make the use of social capital in conducting their affairs (Zinnbauer 2007) and it is taken as a substitute for other types of capital lacking amongst the poor people (Navarra et al. 2013; Quetulio-Navarra et al. 2014). In subsistence based societies strong social network and relationships may play an important role when adjusting to stress (Smit and Wandel 2006). According to Lewis (2010) much as social capital can be mostly considered at the individual level, the benefits can be for both individuals and collective groups. According to Cooke (2015), many practices integrated within the traditional social structure acted as a social safety net for vulnerable displaced households. However, development projects through its effect of displacement disintegrate community's social structure, hence making those displaced to be more vulnerable to impoverishment for several years (Cernea 2000; Terminiski 2011). In her paper Ostrom (1990) argued that, it is difficult to access social capital amidst a large number of heterogeneous individuals 
in an environment that is new and strange. Displacement and resettlement to new environments has implications on social capital and measures employed by the affected people to rebuild their social capital is usually limited (Downing, 1996; Oliver- Smith 2002). The loss of social capital diminishes society's capacity to cope with and recover from non-project related threats (Theodore and Carmen 2007). A study by Randell (2016) in Brazillian Amazon on displacement and resettlement risks revealed that; $17 \%$ lost their original community and $14 \%$ mentioned being far from their family and yet their previous social network often promoted their wellbeing. Some households stated that they missed their original neighbours and friends who had moved far and others stated that, "their formerly united families were now scattered throughout the region". Similarly Tarekegn (2013) found that the resettlement program in Adis Ababa in Ethiopia due to development projects negatively impacted on social ties, norms, trust towards families and traditional institutions. The relocation also contributed to change in people's way of life by leading to individualism characterized by lack of cooperation and networking. The loss of social capital reduces the society's capacity to cope with and recover from non-project related threats (Theodore and Carmen 2007) in the new areas (Oliver-Smith 2009). It is also observed that women, children and other marginalized groups are more affected (Stanley 2004; Cernea 2006; Mehta, 2009; Terminiski 2013) when the resettled people lose social networks. This is because through networks of friends, neighbours and relatives intervention can be used in adaptation and reducing vulnerability to stressors can be sought out easily (Pelling and High 2005).

\subsection{Health Insecurity}

Displaced and resettled communities have greater chances of being exposed to illnesses and more severe diseases, hence becoming more vulnerable than those not displaced and resettled (Terminisk 2013). In developing countries such as India dam construction projects through displacement posed health hazards to the resettled people due to impoverishment, malnutrition and lack of health care services (Bradley 1994). A study in the Philippines and Indonesia indicated that there was a great reduction in the number of basic services including health care services provided in the resettlement site. Due to limited funds, the government received funds in bits to provide such services (Quetulio-Navarra et al. 2014). Lack of food for the displaced people may also result into increased vulnerability to illness due to unbalanced diet (Cao et al. 2012). The nutrition and health of women who is worse than that of men even under normal circumstances, is bound to go down in the event of an overall worsening in health caused by displacement (Terminisk 2012).

Displacement and resettlement leads to psychological trauma, social stress and outbreak of vector borne and water related diseases in the relocation area. Hwang et al. (2007) in their studies on the three Gorges dam project in China found that there was a positive correlation between migration status and depression for the affected migrants than the non-affected. Migration to new areas can either worsen the existing situation where common diseases like malaria, diahorrea, cholera increases or leads to outbreak of new diseases like HIV/AIDS (Meade and Emch 2010). An example can be seen in a study conducted by Tadesse (2007) where one of the respondents reported that sudden relocation exposed resettlers to health hazards due to endemic diseases such as malaria which was in and around the resettlement area. The prevalence of schistosomiasis in Ghana around the Akosombo dam reservoir rose from $1.8 \%$ before resettlement to $75 \%$ among adult lake-side dwellers. About $100 \%$ of the children also suffered from schistosomisaia after the 1960 s due to contaminated drinking water and agrochemical intoxication worsened farmers' health (Terminiski 2013). The increase in diseases and under nutrition, contributed to higher mortality rates as services in the selected relocation areas were the first to be cut. Evidence from a long-term study of the Kariba dam revealed that, resettlement leads to an early increase in mortality rates (Clark et al. 1995). Quantification of the prevalence rate of certain diseases such as those sexually transmitted due to large scale infrastructural development projects has remained difficult (Kravitz et al. 1995).

Women, more than men suffer the negative health consequences of implementing development projects. For example mining activities degrades the economic status of women including malnutrition, health problems and lack of access to basic resources (Adusah Kari-Kari 2012). Therefore, since women play a great role in the sustenance of their families, they may have fewer options than men to cope with vulnerability due to their restricted movements (Thukral 1996; Parasuraman 1993).

\subsection{Food Insecurity}

Loss of livelihood and degradation of local economies due to extraction related development activities increases the risk of affected people in terms of health, food and water security (Wetzlmaier 2012). Resettlement often leads to food insecurity resulting into undernourishment due to sudden reduction in food crop availability and/or incomes. A study by Feyera (2005) in Addis Ababa city of Ethiopia revealed that expanding development projects exposes the displaced peasants to joblessness, hence making them food insecure. In such a situation peasant farmers are forced to depend on vulnerable livelihood that tends to increase their poverty and food insecurity. Mooney (2005) revealed that World Food Programme recognized that the displaced populations suffer particular vulnerabilities with varying degrees, hence increasing their insecurity. A study by UN World Food Programme (2009) 
among resettled households in Trincomalee District in Sri-Lanka revealed that resettlement leads to high food prices. A vast majority of household (97.6\%) stated that food prices were higher than at the time of resettlement (54.1\% of said prices were higher and $43.5 \%$ said much higher). When a household is food insecure, it means higher health risks (Patel et al. 2015).

\section{Why development induced displacement and resettlement risks have continued to occur and remained persistent in developing countries}

Several research (Cernea 1990; 2002; Stanley 2004; Terminiski 2011; Terminiski 2012; Ahsan 2016) on development induced displacement and resettlement through use of the IRR model and other experiences confirm that risks and impoverishment remains the major outcome to project affected persons (De wet 2006). The socioeconomic risks of DIDR may take several years to fade away. In India development projects especially dam construction has displaced over 60 million people, subjecting them to suffering and poverty for several years (Africa Progress Panel 2012). Even though resettlement processes are conducted following the best practices in the world, there will still be some degree of risks and stress (Bisht 2009). A number of reasons account for the occurrence and persistency of these risks especially in developing countries as explained below;

Compensation for loss of properties (Cernea 2008; Symth et al, 2015; Vanclay 2017) is one of the main reasons. Development companies and government authorities in developing countries have often adopted policies of compensation usually in terms of cash (Cernea 1997). In most resettlement situations, compensation is usually unfair and delayed (Vanclay 2017; Aiken and Leigh 2015). Compensation is not enough to rebuild and improve the livelihoods of displaced persons in relocation areas (Cernea 2008). Delayed compensation does not take into consideration the current market prices (Patel et al, 2015), thereby affecting the purchasing power of lost properties and sustenance of livelihoods in relocation areas (Symth et al, 2015). In addition, delayed compensation subjects project affected children to loss of education and suffering such as moving long distance to access safe water (Anyuru et al. 2016). In Zimbabwe, resettlers due to diamond mining were compensated five month later after relocation. In Malaysia, families resettled due to dam construction complained that cash compensation was inadequate and not able to restore their livelihoods as before resettlement.

Lack of experience, commitment and capacity to plan and implement the resettlement processes (Symth et al. 2015; Vanclay and Kemp 2017) is yet another factor to the persistency of displacement and resettlement risks. When developers and concerned government authorities lack experience and are not committed, socioeconomic issues in projects are left unaddressed. In such a situation promises to establish accessible social services such as schools, hospitals, and safe water are made but none is fulfilled (Cernea 1997; International Alert, 2013). For example, families resettled due to dam construction in Malaysia were promised schools, clinics and safe water but all in vain (Madebwa et al. 2011; Aiken and Leigh 2015).

Lack of special consideration of certain socially vulnerable groups such as women, children and the elderly (Cernea 1997). The risks of displacement and resettlement have persisted on women because they tend to be ignored and excluded in planning and restoration programmes, leading to their impoverishment (Symth et al. 2015). In some instances, women are also denied land ownership and cash compensations. In countries such as China, Tanzania, Ghana, Uganda women are denied land during compensation and yet land remains their main source of food and income. Women still follow culture which also denies them rights to land when they marry (Wilmsen 2011). An example can be seen in Malawi where resettled women due to large land; acquisition were denied cash compensation and instead given to husbands.

\section{Discussions}

This paper has attempted to contribute to the discussion on risks related to development induced displacement and resettlement through reviewing literature with consideration to the IRR model. Findings indicated that the project affected people exposed to displacement and resettlement face more risks than opportunities. The risks described; landlessness, homelessness, joblessness, social disintegration, loss of common property resources, food insecurity, marginalization and increased morbidity and mortality indicates that the numerous researches on development induced displacement and resettlement risks agrees with Cernea's findings. Although all the risks cause impoverishment to project affected people, loss of land and social networks stresses the more. Land and employment are some of the basic livelihood assets that contribute towards livelihood restoration of displaced households. When land is lost to development projects, it might be forever, sometimes partially or fully replaced, or fully compensated. Loss of land results into other risks such as loss of access to common resources; water, grazing land, forests that most rural livelihoods are dependent on. Loss of land greatly affects the productive systems, commercial activities, residence and livelihoods of households. According to the findings, development induced displacement and resettlement risks are interlinked and vary from place to place, household to household and among groups as indicated by (Cernea 2005). Particular categories of project affected persons such as women, the elderly and children are more impoverished by the livelihood risks, hence becoming more vulnerable than before displacement and resettlement episode. The 
vulnerable categories experience the greatest impacts due to their inherent social vulnerabilities. Employing the framework developed above in analyzing risks of any displacement and resettlement would widen one's knowledge and understanding not only on the risks experienced but also the resultant consequences of those risks identifying both the positive and negative. Since development induced displacement and resettlement risks identified by Cernea in his IRR model have been tested, confirmed and known through research and other experiences, the fact that these risks have persisted in most developing countries such as China, India, Nigeria, Ghana, Sudan, Tanzania, Angola and Uganda, considering the reasons behind the persistency of those risks would be important. Cash compensation and lack of commitment and capacity by developers and government authorities to handle the resettlement process are some of the main factors accounting for the persistency of the risks and impoverishments of large scale infrastructural development projects. Compensation in general affects abilities of families to sustain their livelihoods because prices of assets such as land are highly increased, yet the compensation rate in usually low and delayed. Government authorities are often slow at responding to resettlement processes there by affecting displaced and resettled families. Compensation if not handled well, remains one of the root causes of DIDR risks. Although populations in most developing countries have at least experienced displacement and resettlement risks of large scale development projects, China and India in Asia remain dominant. According to literature, over 100 millions of people in China and India have been displaced and resettled due to development projects, especially dam construction.

\section{Conclusions}

Development projects though are associated with numerous consequences; they are largely associated with risks due to displacement and resettlement processes. These risks as indicated by most research findings, cause impoverishments and deterioration to the livelihoods of resettled households and vulnerable categories of people such as the women, poor households and the elderly. These eight interlinked risks identified through the IRR model must be seen as a set of potential and high probability risks that will likely become real and heighten vulnerability of resettled people if unaddressed or even avoided at an earlier stage if anticipated. The enormous body of data through research confirming the risks and impoverishments caused by displacement and resettlements due to large scale development projects such as dams, highways, industries require the need for concerned authorities and developers to take up actions that could avert the situation. Proper planning and implementation of resettlement processes is necessary for social issues to be sustainably handled. Addressing the livelihood risks associated to development induced displacement and resettlement could contribute towards minimizing socio-economic vulnerability associated with large scale development projects among the affected communities.

Further review papers on the consequences of development induced displacement and resettlement focusing on risks, should consider risks beyond the eight in the IRR model as introduced by Downing (2002). The study also recommends further research in certain areas such as risks beyond the IRR model and the need to investigate about other reasons contributing to the occurrence and persistency of these risks.

\section{REFERENCES}

[1] Adusah-Karikari, A. (2015). Black gold in Ghana: Changing livelihoods for women in communities affected by oil production. The Extractive Industries and Society, 2(1), 24-32.

[2] Aiken, S. R., \& Leigh, C. H. (2015). Dams and indigenous peoples in Malaysia: development, displacement and resettlement. Geografiska Annaler: Series B, Human Geography, 97(1), 69-93.

[3] Al Atahar, S. (2010). Development project, land acquisition and resettlement in Bangladesh; a quest for well formulated national resettlement and rehabilitation policy. Star.

[4] Ambaye, G., \& Abeliene, A. (2015). Development-Induced Displacement and Its Impacts on the Livelihoods of Poor Urban Households in Bahir Dar, North Western Ethiopia. African Human Mobility Review, 1(3), 310-331.

[5] Anyuru, M. A., Rhoads, R., Mugyenyi, O., Ekwenyu, J., \& Balemesa, T., (2016) Balancing Development and Community Livelihoods: A Framework for Land Acquisition and Resettlement in Uganda. ACODE Policy Research Series No.75.

[6] Behrman, J., Meinzen-Dick, R., \& Quisumbing, A. (2012). The gender implications of large-scale land deals. Journal of Peasant Studies, 39(1), 49-79.

[7] Bessey, F.O and Tay, P.O., (2015) Resettlement Induced Secondary Poverty in Developing Countries. Developing Country Studies www.iiste.org. ISSN 2224-607X (Paper) ISSN 2225-0565 (Online).

[8] Bond, C. J., \& Kirsch, P. (2015). Vulnerable populations affected by mining: Predicting and preventing outbreaks of physical violence. The Extractive Industries and Society, 2(3), 552-561.

[9] Boohene, R., \& Peprah, J. A. (2011). Women, livelihood and oil and gas discovery in Ghana: An exploratory study of Cape Three Points and surrounding communities. Journal of sustainable development, 4(3), 185.

[10] Bose, P. S. (2016). Vulnerabilities and displacements: 
adaptation and mitigation to climate change as a new development mantra. Area, 48(2), 168-175.

[11] Bozigar, M., Gray, C. L., \& Bilsborrow, R. E. (2016). Oil extraction and indigenous livelihoods in the northern Ecuadorian Amazon. World development, 78, 125-135. Bradley, D., 1994. Health, environment and tropical development. In: Cartledge, B. (Ed.), Health and the Environment. Oxford University Press, Oxford

[12] Cao, Y., Hwang, S. S., \& Xi, J. (2012). Project-induced displacement, secondary stressors, and health. Social science \& medicine, 74(7), 1130-1138.

[13] Caspary, G. (2007). The impacts of development-induced displacement on human security. Human Security Journal, 4, 70-81.

[14] Cernea, M (2000b), "Risks, Safeguards and Reconstruction: A Model for Population Displacement and Resettlement", in M Cernea and C McDowell (editors), Risks and Reconstruction: Experiences of Resettlers and Refugees, World Bank, Washington, DC Cernea, M. (1997). The risks and reconstruction model for resettling displaced populations. World development, 25(10), 1569-1587.

[15] Cernea, M. M. (1990). Internal refugee flows and development-induced population displacement. Journal of Refugee Studies, 3(4), 320-339.

[16] Cernea, M. M. (2000) 'Risks, Safeguards and Reconstruction: A Model for Population Displacement and Resettlement'. Economic and Political Weekly, 7.

[17] Cernea, M. M. (2006). Re-examining "displacement": a redefinition of concepts in development and conservation policies. Social Change, 36(1), 8-35.

[18] Cernea, M. M. (2009). Introduction: Resettlement-an enduring issue in development. The Asia Pacific Journal of Anthropology, 10(4), 263-265.

[19] Chakravorty, S. (2013). The price of land: acquisition, conflict, consequence. New Delhi: Oxford University Press.

[20] Chakroborty, U. K., \& Narayan, B. (2014). Socio-economic Issues and Dilemmas of Mining Induced Displacement: A Case of Coal Mining Industry. Journal of Economic \& Social Development, 10(2).

[21] Clark, S., Colson, E., Lee, J., \& Scudder, T. (1995). Ten thousand Tonga: a longitudinal anthropological study from southern Zambia, 1956-1991. Population Studies, 49(1), 91-109.

[22] Cooke, J. G. (2015). The state of African resilience: Understanding dimensions of vulnerability and adaptation.

[23] De Wet, C. (Ed.). (2006). Development-induced displacement: Problems, policies and people. Berghahn Books.

[24] Downing, T. E. (2002). Avoiding new poverty: mining-induced displacement and resettlement (Vol. 52). London, UK: International Institute for Environment and Development.

[25] Downing, T. E., \& Garcia-Downing, C. (2009). Routine and dissonant cultures: A theory about the psycho-socio-cultural disruptions of involuntary displacement and ways to mitigate them without inflicting even more damage.

\section{Development and Dispossession.}

[26] Eriksen, S. H., Brown, K., \& Kelly, P. M. (2005). The dynamics of vulnerability: locating coping strategies in Kenya and Tanzania. The geographical journal, 171(4), 287-305.

[27] Fernandes, W. (2008). India's forced displacement policy and practice: Is compensation up to its functions. Can compensation prevent impoverishment, 181-207.

[28] Feyera, A. (2005). Urban Expansion and the Livelihood of the Peri-urban Agricultural Community: The Case of Addis Ababa.

[29] Golombok, R., \& Jones, M. I. (2015). Oil Governance in Uganda and Kenya: A.

[30] Guha, A. (2007). Peasant resistance in West Bengal a decade before Singur and Nandigram. Economic and Political weekly, 3706-3711.

[31] Hoshour, K., \& Kalafut, J. (2010). A growing global crisis: development-induced displacement and resettlement. Issue Paper, International Accountability Project.

[32] Hwang, S. S., Xi, J., Cao, Y., Feng, X., \& Qiao, X. (2007). Anticipation of migration and psychological stress and the Three Gorges Dam project, China. Social Science \& Medicine, 65(5), 1012-1024.

[33] International Alert. (2013). Governance and livelihoods in Uganda's Oil-rich Albertine Graben. International Alert.

[34] Kabra, A., \& Mahalwal, S. (2014). Impact of conservation-induced displacement on host community livelihoods: Complicating the DIDR narratives. Land Use Policy, 41, 217-224.

[35] Koricheva, J., Gurevitch, J., \& Mengersen, K. (Eds.). (2013). Handbook of meta-analysis in ecology and evolution. Princeton University Press.

[36] Kravitz, J. D., Mandel, R., Petersen, E. A., Nyaphisis, M., \& Human, D. (1995). Human immunodeficiency virus seroprevalence in an occupational cohort in a South African community. Archives of internal medicine, 155(15), 1601-1604. Lewis, J. M. (2010). Connecting and Cooperating: social capital and public policy. UNSW press.

[37] Lin, N., Fu, Y. C., \& Hsung, R. M. (2001). Measurement techniques for investigations of social capital. LIN, N.; GRUYTER, A. Social capital: theory and research. New York. Lund, R. (2017). Gendered Entanglements: Revisiting Gender in Rapidly Changing Asia. Asian Theatre Journal, 34(2).

[38] Madebwe, C., Madebwe, V., \& Mavusa, S. (2011). Involuntary displacement and resettlement to make way for diamond mining: the case of Chiadzwa villagers in Marange, Zimbabwe. Journal of Research in Peace, Gender and Development, 1(10), 292-301.

[39] Mahapatra, L. K. (1999). Reconstruction Model on India's Resettlement Experiences'. The economics of involuntary resettlement: Questions and challenges, 189-230.

[40] Manjula, K., Kumar, T. A., \& Aneesh, K. A. (2013). Impact of Development Induced Displacement in Kerala, India. Journal of Internal Displacement, 3(1), 2-18.

[41] Marshall, N. A., Stokes, C. J., Webb, N. P., Marshall, P. A., 
\& Lankester, A. J. (2014). Social vulnerability to climate change in primary producers: A typology approach. Agriculture, Ecosystems \& Environment, 186, 86-93.

[42] Mathur, H.M., (2013). Displacement and Resettlement in India: The Human Cost of Development. Abingdon, Oxon, Routledge.

[43] Meade, M. S., \& Emch, M. (2010). Medical geography. 3rd.Edition.

[44] Mehta, L. (2002). 'Engendering Resettlement Policies and Programmes in India, New Delhi September 12 and 13, 2002.

[45] Mehta, L. (2009). Displaced by development: confronting marginalization and gender injustice. Sage Publications.

[46] Ministry of Energy and Mineral Development., (2012), Resettlement Action Plan for the Propose Acquisition of land for the oil and refinery in Kabaale parish, Buseruka sub-county, Hoima District. Petroleum Exploration and Mineral Department. Strategic Friends International Limited.

[47] Mooney, E. (2005). The concept of internal Displacement and the case for Internally Displaced Persons as a category of concern. Refugee Survey Quarterly Vol 24, issue 3.

[48] Muggah, H. R. (2000). Conflict-induced displacement and involuntary resettlement in Colombia: Putting Cernea's IRLR model to the test. Disasters, 24(3), 198-216.

[49] Navarra, M. Q., Niehof, A., \& van der Vaart, W. (2013). Social capital in involuntary displacement and resettlement. International Journal of Social Sciences and Humanity Studies, 5(2), 139-154.

[50] Oliver-Smith (2002). Displacement, Resistance and the Critique of Development: From the grass-roots to the global, RSC Working Paper, No. 9, Refugee Studies Centre, University of Oxford.

[51] Oliver-Smith, A. (2005). Applied anthropology and development-induced displacement and resettlement. Kedia, S.; can Willigen, J. (Eds): Applied Anthropology: Domains of Application. Praeger Publishers, Westport, USA, 189-219.

[52] Oliver-Smith, A. (2009). Climate change and population displacement: disasters and diasporas in the twenty-first century. Anthropology and climate change. From encounters to actions, 116-136.

[53] Oruonye, E. D., (2012). An Assessment of the Socio-Economic Impact of Urban Development-Induced Resettlement Scheme in Nigerian Cities: A Case Study of the Nyamusala - ATC Road Construction in Jalingo Metropolis, Taraba State. Vol. 3, No. 1 (2012), pp. 1-9

[54] Ostrom, E. (1990). Crafting irrigation institutions: social capital and development. Associates in Rural Development, Incorporated.

[55] Pandey, B. and Associates (1997). Development, Displacement and Rehabilitation in Orissa 1950-1990. International Development Research Centre, Canada, and Institute for Socio-Economic Development, Bhubaneswar.

[56] Panel, A. P. (2012). Africa Progress Report 2012-Jobs. Justice and Equity: Seizing Opportunities in Times of Global
Change, Geneva.

[57] Partridge, W. L. (1989). Involuntary resettlement in development projects. J. Refugee Stud., 2, 373

[58] Patel, S., Sliuzas, R., \& Mathur, N. (2015). The risk of impoverishment in urban development-induced displacement and resettlement in Ahmedabad. Environment and Urbanization, 27(1), 231-256.

[59] Pelling, M., \& High, C. (2005). Understanding adaptation: what can social capital offer assessments of adaptive capacity? Global Environmental Change, 15(4), 308-319.

[60] Perera, J. (Ed.). (2014). Lose to Gain: Is Involuntary Resettlement a Development Opportunity?. Asian Development Bank.

[61] Prenzel, P. V., \& Vanclay, F. (2014). How social impact assessment can contribute to conflict management. Environmental Impact Assessment Review, 45, 30-37.

[62] Quetulio-Navarra, M., Niehof, A., Van der Horst, H., \& van der Vaart, W. (2014). Short-term risk experience of involuntary resettled households in the Philippines and Indonesia. Habitat International, 41, 165-175.

[63] Rajagopal, B. (2000). Human Rights and Development. World Commission on Dams Submission, www.dams.org/kbase/submissions/showsub.php.

[64] Randell, H. (2016). the short-term impacts of development induced displacement on wealth and subjective well-being in the Brazilian Amazon

[65] Robinson, W. C. (2003). Risks and rights: The causes, consequences, and challenges of development-induced displacement. Occasional Paper.

[66] Rodhouse, T., \& Vanclay, F. (2016). Is free, prior and informed consent a form of corporate social responsibility?. Journal of Cleaner Production, 131, 785-794.

[67] Sahoo, D., \& Mishra, N. (2016). Development-Induced Displacement and Gender Injustice: Some Critical Reflections. Journal of Politics and Governance, 5(4), 19-30.

[68] Smit, B., Wandel, J., (2006). Adaptation, adaptive capacity and vulnerability. Global Environmental Change 16 (3), 282-292.

[69] Smyth E, Steyn M, Esteves AM, Franks DM, Vaz K. (2015). Five 'big' issues for land access, resettlement and livelihood restoration practice: findings of an international symposium. Impact Assess Project Appraisal. 33:220-225.

[70] Somayaji, S., \& Talwar, S. (Eds.). (2011). Developmentinduced Displacement, Rehabilitation and Resettlement in India: Current Issues and Challenges. Taylor \& Francis.

[71] Stanley, J. (2004). Development-induced displacement and resettlement. Forced Migration Online.

[72] Tadesse, A. (2007). Resettlement and food security with reference to the Ethiopian experience: The Boreda case. Catholic Church Community Based Integrated Development Program, Southern region of Ethiopia.

[73] Tarekegn, F. (2013). The impact of development induced displacement on social capital in Addis Ababa: An 
implication for rebuilding social capital. (Masters dissertation, Addis Ababa University, Ethiopia). Retrieved from https://www.academia.edu/8936166/ Terminski, B. (2011). Oil-induced displacement and resettlement: Social problem and human rights issue.

[74] Terminski, B. (2012). Mining-induced displacement and resettlement: social problem and human rights issue (a global perspective). Retrieved July, 25, 2013.

[75] Terminski, B. (2013). Development-Induced Displacement and Resettlement: Social Problem and Human Rights Issue.

[76] Thukral, E. G. (1996). Development, displacement and rehabilitation: Locating gender. Economic and Political Weekly, 1500-1503.

[77] Tilt, B., Braun, Y., \& He, D. (2009). Social impacts of large dam projects: A comparison of international case studies and implications for best practice. Journal of environmental management, 90, S249-S257.

[78] Tsikata, D. (2009). Gender, land and labour relations and livelihoods in sub-Saharan Africa in the era of economic liberalization: Towards a research agenda. Feminist Africa, 12 .

[79] UN-WFP (2009). Food Security Assessment in Resettled Households - Trincomalee District Srilanka.

[80] Vagholikar, N., \& Das, P. (2010). Damming Northeast India: Juggernaut of hydropower projects threatens social and environmental security of the region." published by Kalpavriksh. Aaranyak and ActionAid India. Available on: http://chimalaya.files.Wordpress.Com/2010/12/damming-n ortheast-india-final.pdf.

[81] Vanclay F. (2012). The potential application of social impact assessment in integrated coastal zone management. Ocean Coast Manage. 68:149-156.

[82] Vanclay, F. (2017). Project-induced displacement and resettlement: from impoverishment risks to an opportunity for development? Impact Assessment and Project Appraisal, $35(1), 3-21$.

[83] Vanclay, F., \& Kemp, D. (2017). Displacement, resettlement and livelihoods. Impact Assessment and Project Appraisal, 35:1, 2-2, DOI:10.1080/14615517.2016.1272212

[84] Vanclay, F., Esteves, A. M., Aucamp, I., \& Franks, D. M. (2015). Social Impact Assessment: Guidance for assessing and managing the social impacts of projects.

[85] Veit, P. G., \& Benson, C. (2004). When parks and people collide. human rights dialogue, 2(11), 13-4.

[86] Vivoda,V., Owen, J., Kemp, D. (2017). Applying the Impoverishment Risks and Reconstruction (IRR) Model to Involuntary Resettlement in the Global Mining Sector. Centre for Social Responsibility in Mining (CSRM), University of Queensland.

[87] Wetzlmaier, M. (2012). Cultural Impacts of Mining in Indigenous Peoples' Ancestral Domains in the Philippines. Austrian Journal of South-East Asian Studies, 5(2), 335. Wilmsen, B. (2016). After the Deluge: A longitudinal study of resettlement at the Three Gorges Dam, China. World Development, 84, 41-54.

[88] Wilmsen, B., Webber, M., \& Yuefang, D. (2011).
Development for whom? Rural to urban resettlement at the Three Gorges Dam, China. Asian Studies Review, 35(1), 21-42.

[89] Yenneti, K., Tripathi, S., Wei, Y. D., Chen, W., \& Joshi, G. (2016). The truly disadvantaged? Assessing social vulnerability to climate change in urban India. Habitat International, 56, 124-135.

[90] Zinnbauer, D. (2007). What can Social Capital and ICT do for Inclusion. Institute for Prospective Technological Studies (IPTS)-JRC-European Commission EUR, 22673.

[91] Zmerli, S. (2010). Social capital and norms of citizenship: an ambiguous relationship? American Behavioral Scientist, 53(5), 657-676. 